\title{
PARA ALÉM DAS POLÍTICAS DA DIVERSIDADE: interfaces da educação especial e da educação do campo
}

\author{
Washington Cesar Shoiti Nozu \\ Universidade Federal da Grande Dourados - UFGD \\ Marilda Moraes Garcia Bruno \\ Universidade Federal da Grande Dourados - UFGD
}

\begin{abstract}
Resumo
Este ensaio trata, a partir de teorizações pós-críticas, das interfaces da Educação Especial e da Educação do Campo, no âmbito das políticas educacionais brasileiras produzidas para o atendimento às demandas das diversidades. Para tanto, analisa os dispositivos e os regimes de verdade da Educação Especial e da Educação do Campo para, então, problematizar as suas interfaces e a constituição de outras miradas que questionem os essencialismos biológicos e culturais e multipliquem, na perspectiva das diferenças, os sujeitos, os tempos e os espaços educativos envolvidos nessa articulação político-pedagógica. Nesse processo, o texto compreende que "entre as faces" da Educação Especial e da Educação do Campo tem-se sujeitos, espaços e tempos educativos múltiplos. Assim, acena para a emergência do reconhecimento e do tensionamento das diferenças dentro das diferenças, com vistas à concepção das interfaces Educação Especial Educação do Campo como tempos-espaços de negociações e de traduções culturais, nos quais identidades e diferenças são produzidas e posicionadas discursivamente nas relações de saber-poder presentes tanto nas políticas educacionais quanto no cotidiano escolar.
\end{abstract}

Palavras-chave: Educação Inclusiva; Identidades; Diferenças.

\begin{abstract}
This essay deals, based on post-critical theorizing, with the interfaces of Special Education and Rural Education, within the scope of Brazilian educational policies produced to provide services to diversity's demands. Therefore, it analyzes the devices and truth regimes of Special Education and Rural Education, in order to problematize their interfaces and the constitution of other perspectives that question the biological and cultural essentialisms and multiply, in the perspective of differences, the subjects, the times and the educational spaces involved in this political-pedagogical articulation. In this process, the text understands that "between the faces" of Special Education and Rural Education there are multiple educational subjects, spaces and times. Thus, it points to the emergence of the recognition and tensioning of differences within differences, aiming at the conception of the interfaces Special Education - Rural Education as times-spaces of negotiation and cultural translation, in which identities and differences are produced and positioned discursively in the knowledge-power relations present in both educational policies and school daily life.
\end{abstract}

Keywords: Inclusive Education; Identities; Differences. 


\section{Introdução}

As interfaces Educação Especial e Educação do Campo instituem uma nova e instigante seara de investigação, capaz de produzir problematizações de conceitos estabelecidos, de colocar em suspeição verdades difundidas e, principalmente, de tensionar práticas pedagógicas tradicionalmente adotadas em ambas as propostas educativas.

Educação Especial e Educação do Campo constituem-se, historicamente, em ações diferenciadas que atuam na formação de determinados sujeitos - demarcados em um processo de diferenciação operacionalizado a partir da instituição arbitrária da norma e de suas consequentes estratégias de normalização. Nesse sentido, a marcação da diferença do sujeito "deficiente" e do sujeito "rural", em uma lógica binária e essencialista, torna-se componente chave para que se estabeleça um processo de normalização.

Essas estratégias de poder articulam-se aos saberes pedagógicos da educação do sujeito "deficiente" e da educação do sujeito "rural", constituindo, no tempo-espaço, regimes de verdade que direcionam, discursivamente, os processos formativos e o estabelecimento de significações acerca do "por que", do "como" e de "onde" estes devem ser educados.

A partir das contribuições das teorizações pós-críticas, este ensaio tem por objetivo analisar os dispositivos e os regimes de verdade que circularam/circulam na Educação Especial e na Educação do Campo, no conjunto das políticas educacionais da diversidade, para, assim, problematizar as suas interfaces e a constituição de outras miradas que questionem os essencialismos e multipliquem, na perspectiva das diferenças, os sujeitos, os tempos e os espaços educativos envolvidos nessa articulação político-pedagógica.

Para tanto, nesse texto, enfatizamos os discursos que operaram/operam como verdadeiros na educação do sujeito "deficiente" (institucionalização, integração e inclusão) e na educação do sujeito "rural" (educação rural e educação no/do campo), de modo a evidenciar como se cruzam, repelem-se e se excluem no processo de normalização destes sujeitos, produzindo significados, legitimando ou interditando certos enunciados.

Assim, apresentamos os dispositivos e as tendências atuais da Educação Especial e da Educação do Campo, que colocam em pauta identidades que requerem um processo específico e diferenciado de educação. Nesse jogo político pelo alcance do direito à educação, as identidades e as diferenças dos sujeitos da Educação Especial e da Educação do Campo acabam sendo essencializadas e cristalizadas, ora biologicamente ora culturalmente, e, dessa maneira, sendo contempladas no conjunto das políticas da diversidade.

Tais políticas tendem a naturalizar os sujeitos "deficientes" e os sujeitos "rurais", fomentando representações político-pedagógicas estáticas sobre eles. Diante dessa situação, os dispositivos da diversidade contentam-se em celebrar as diferenças desses sujeitos, aos quais, tidos como exóticos, são destinadas apenas recomendações pedagógicas de respeito e tolerância (SILVA, T., 2014).

A partir desse cenário, entendemos que as relações estabelecidas entre Educação Especial e Educação do Campo precisam ir além das políticas da diversidade, de modo a questionar as relações de poder que produzem as diferenças e permitir o "cruzamento de fronteiras" que demarcam, artificialmente, os limites entre os territórios das diferentes 
identidades (SILVA, T., 2014). Em outras palavras, é preciso avançar de uma política da diversidade para uma política das diferenças.

\section{Educação Especial e Educação do Campo: estratégias de normalização do sujeito "deficiente" e do sujeito "rural"}

Entendemos a educação como um conjunto de práticas discursivas e não discursivas que atuam, contingencialmente, no processo de constituição dos sujeitos. Isso porque "todo sistema de educação é uma maneira política de manter ou de modificar a apropriação dos discursos, com os saberes e os poderes que eles trazem consigo" (FOUCAULT, 2010a, p. 44).

Nesse sentido, temos que a Educação Especial e a Educação do Campo são dispositivos de saberes-poderes que funcionam como instrumentos para que os seus sujeitos-alvos tenham acesso aos discursos necessários para a performance na vida social e, simultaneamente, como tecnologias de esquadrinhamento, conhecimento e controle, bem como de produção, formação e constituição de sujeitos específicos, cuja atuação dar-se-á em um situado tempoespaço.

Assim, consideramos a Educação Especial e a Educação do Campo, ressalvadas suas especificidades, como tramas de saberes, poderes e sujeitos. Saberes produzidos por teorias, práticas pedagógicas, estratégias, procedimentos e metodologias de ensino. Poderes que atravessam desde a elaboração das políticas educacionais até o governamento dos sujeitos docentes e discentes no cotidiano escolar. Sujeitos que são efeitos de saberes e poderes aos quais são submetidos ou de resistências e contracondutas empreendidas nas práticas de si.

Importa-nos, nessa seção, pinçar alguns discursos sobre a educação dos sujeitos "deficientes" e a educação dos sujeitos "rurais", com vistas a evidenciar alguns deslocamentos político-pedagógicos nos processos de normalização destes.

Em face dessa empreitada, precisamos, de antemão, fazer alguns esclarecimentos: a) não pretendemos aqui realizar uma análise historiográfica da educação do sujeito "deficiente" e da educação do sujeito "rural", mas apresentar os principais "regimes de verdade" (FOUCAULT, 2010b) que giraram/giram em torno dessas propostas educativas; b) o uso das expressões "deficiente" e "rural" é intencional e demarca nossa denúncia aos processos marginais, periféricos e essencialistas de constituição desses sujeitos, que, de maneira binária, colocaram-nos como sendo o avesso do sujeito "eficiente" e "urbano", e, portanto, como alvo de práticas de normalização.

Conforme Foucault (2010c), a norma se estabelece como regra de conduta, como princípio de conformidade, como pretensão de poder. De um lado, a norma converte-se em um critério de divisão dos sujeitos: aqueles que se enquadram e os que não se enquadram na norma, em outras palavras, o normal e o anormal.

Assim, para Foucault (2010d, p. 176), a norma: a) relaciona os atos, os desempenhos, os comportamentos dos sujeitos a um domínio, "que é ao mesmo tempo campo de comparação, espaço de diferenciação e princípio de uma regra a seguir"; b) diferencia os sujeitos com base 
nesse domínio, nessa regra; c) mede em termos quantitativos e hierarquiza em termos de valor as capacidades dos sujeitos; d) faz funcionar, a partir da valorização das condutas, uma conformidade a ser alcançada, buscando, assim, homogeneizar os comportamentos dos sujeitos; e) traça "o limite que definirá a diferença em relação a todas as diferenças, a fronteira externa do anormal". Portanto, a norma "compara, diferencia, hierarquiza, homogeniza [sic], exclui" (FOUCAULT, 2010d, p. 176).

Nesses jogos de diferenciação, os sujeitos "deficientes" e os sujeitos "rurais" são alocados como sujeitos anormais, que desviam do modelo mercadológico da eficiência e civilizado do urbano, e, portanto, têm suas capacidades inferiorizadas, suas condições de existência marginalizadas e seus comportamentos estereotipados.

Para Fleuri (2006, p. 498), o estereótipo "indica um modelo rígido a partir do qual se interpreta o comportamento de um sujeito social, sem se considerar o seu contexto e a sua intencionalidade. $O$ estereótipo representa uma imagem mental simplificadora de determinadas categorias sociais". Dessa maneira, "funciona como um padrão de significados utilizado por um grupo na qualificação do outro" e, destarte, "constitui imagens que cumprem o papel de criar ou acentuar a diversidade" (FLEURI, 2006, p. 498). Nesse processo, os sujeitos tendem a ser considerados como fixos, imutáveis e estáveis, sendo, portanto, passíveis de técnicas de normalização.

Assim, a lógica moderna binária é operacionalizada tomando o sujeito "eficiente" e "urbano" para elaboração arbitrária da norma e, a partir daí, criar as anomalias do sistema, nomeando-as, esquadrinhando-as, controlando-as e regulando-as no conjunto das normalidades. Isso porque, como nos ensina Foucault (2008, p. 83), “o normal é que é primeiro, e a norma se deduz dele, ou é a partir desse estudo das normalidades que a norma se fixa e desempenha seu papel operatório".

Além de distinguir o normal do anormal, é preciso ter uma identificação das diferentes curvas de normalidade, sendo que "a operação da normalização vai consistir em fazer essas diferentes distribuições de normalidade funcionarem uma em relação às outras e [em] fazer de sorte que as mais desfavoráveis sejam trazidas às que são mais favoráveis" (FOUCAULT, 2008, p. 83).

Por conseguinte, a dinâmica da normalização se dá em procedimentos de exclusãoinclusão: categorizam-se sujeitos como normais e anormais ("deficientes" e "eficientes" e "rurais" e "urbanos"), fixando-lhes imagens sectarizadas, absolutizadas e reducionistas que são significadas nas políticas das diversidades tendentes a promover as relações sociais e a integração entre os sujeitos, naturalizando as diferenças e corrigindo os desníveis nas fronteiras da normalidade.

Em sua operacionalização, a normalização entrecruza tecnologias biopolíticas e disciplinares (FOUCAULT, 2008, 2010e). Estas são centradas no corpo do indivíduo e atuam por meio de atividades de treinamento, de vigilância, de distribuição dos espaços e de controle do tempo, desenvolvidas principalmente no âmbito das instituições. Aquelas focalizam as populações e as massas humanas, conhecendo-as e regulando-as mediante o uso de precisões, números, estimativas estatísticas, recenseamentos, medições globais no conjunto do aparato estatal. 
Sintetizando, conforme Foucault (2010e, p. 210), temos duas séries que se articulam no processo de normalização: "a série corpo - organismo - disciplina - instituições; e a série população - processos biológicos - mecanismos regulamentadores - Estado". De um lado, a organodisciplina da instituição manipula o corpo do indivíduo de modo a torná-lo útil economicamente e dócil politicamente. De outro lado, a biorregulamentação pelo Estado que agrupa os efeitos de massa próprios de uma população, procurando controlar a ocorrência e a probabilidade de eventos fortuitos e compensar seus efeitos.

Dito isto, entendemos que as estratégias para educar o sujeito "deficiente" e o sujeito "rural" funcionaram/funcionam como processos disciplinadores e biorregulamentadores e instituem "regimes de verdade" que acolhem determinados discursos e desprezam outros, fazendo-os funcionar como verdadeiros ou falsos nas dinâmicas sociais, políticas e pedagógicas. Assim, reiteramos nossa concepção de

[...] que o poder produz saber (e não simplesmente favorecendo-o porque o serve ou aplicando-o porque é útil); que poder e saber estão diretamente implicados; que não há relação de poder sem constituição correlata de um campo do saber, nem saber que não suponha e não constitua ao mesmo tempo relações de poder (FOUCAULT, 2010d, p. 30).

Nessa diretiva, cumpre-nos, depois de termos enfatizado que o sujeito "deficiente" e o sujeito "rural" constituem-se nas relações de poder-saber, tratar dos regimes de verdade que circularam/circulam na seara da educação do sujeito "deficiente" e na educação do sujeito "rural", evidenciando, no contexto brasileiro, alguns discursos e deslocamentos.

No que concerne à educação do sujeito "deficiente", identificamos três regimes que funcionaram/funcionam, em dados tempos-espaços, como discursos verdadeiros: a institucionalização, a integração e a inclusão (ARANHA, 2001; MENDES, 2006, 2010; GLAT; BLANCO, 2009; GLAT; PLETSCH, 2011; NOZU, 2013).

A institucionalização, configurada com base no discurso médico da deficiência ${ }^{2}$, foi a primeira estratégia educativa de atenção ao sujeito "deficiente", sendo que as primeiras entidades destinadas a este fim foram criadas por volta do século XVII, no bojo de outras organizações ocidentais tais como as prisões, os hospitais, as fábricas, os manicômios (ARANHA, 2001). Esse regime de verdade agrupou os enunciados que enfatizam a possibilidade de aprender do sujeito "deficiente" e que estabelecem as instituições especializadas como os espaços mais adequados para a oferta da educação desse sujeito.

Esses espaços comumente especializam-se no atendimento de uma categoria de deficiência (visual, auditiva, intelectual, motora) e funcionam em regime de internato, semiinternato ou externato. Neles foram/são ofertados cuidados relacionados à condição de deficiência do sujeito, a partir de atividades terapêuticas, assistenciais, de ensino especializado e de reabilitação, com o intuito de promover a autonomia dos sujeitos "deficientes".

A proposta e a dinâmica das instituições especializadas passaram a sofrer diversas e severas críticas, mormente a partir da publicação da Declaração Universal dos Direitos 
Humanos no pós Segunda Guerra, que têm questionado desde a sua organização baseada na categorização, passando pela denúncia de práticas segregativas e de isolamento do convívio social e desembocando nos altos custos econômicos de sua manutenção e funcionamento.

Assim, diante da emergência de outras relações de poder-saber, outro regime de verdade passou a ser adotado na educação do sujeito "deficiente": a integração. O enunciado de que o sujeito "deficiente" pode ser integrado na escola comum tornou-se "a matriz política, filosófica e científica da Educação Especial” (GLAT; BLANCO, 2009, p. 21).

A proposta de integração configurava-se em um "sistema de cascatas" (MENDES, 2010), que previa o trânsito progressivo do sujeito "deficiente" de um ambiente segregado (escola especial, instituições especializadas e ambientes hospitalares), passando por um espaço intermediário (classe especial em uma escola comum), até chegar a um local considerado como integrador (classe comum em uma escola comum).

A integração, assim como a proposta da institucionalização, concebia a deficiência a partir do discurso médico, e, portanto, direcionava a educação do sujeito "deficiente" nas escolas e nas classes especiais a partir de um viés de preparação, aptidão e prontidão para acessar às classes comuns. Contudo, ao fixar nos sujeitos "deficientes" a responsabilidade pelo seu sucesso ou fracasso, sem alterações nas estruturas sociais, as progressões para as classes comuns raramente aconteciam, o que ocasionava a permanência ad aeternum desses alunos nas escolas e nas classes especiais e atravancava, dessa forma, o processo integrador.

Logo, abriu-se espaço para a problematização deste modus operandi da educação do sujeito "deficiente", sobretudo pela atuação dos movimentos sociais das/pelas pessoas com deficiência, que passaram a exigir participação plena e igualdade de oportunidades no acesso aos bens materiais e imateriais produzidos pela cultura, a datar da década de $1970^{3}$.

Nesse processo, outra concepção da deficiência passou a ganhar destaque, competindo com o discurso médico: o discurso social da deficiência ${ }^{4}$. A partir dessas novas configurações de poder-saber, principalmente na década de 1990, constituiu-se o atual regime de verdade da educação do sujeito "deficiente": a inclusão.

Ao direcionar a atenção aos elementos extrínsecos (ambientais, culturais e sociais) ao sujeito, a inclusão coloca em funcionamento o enunciado de que o sujeito "deficiente" deve ser incluído na escola comum, delegando a esta a incumbência de eliminar as barreiras didáticas, físicas e atitudinais que dificultam o acesso, a participação e a aprendizagem dos sujeitos "deficientes". Ademais, a inclusão emerge da confluência de discursos relacionados aos direitos humanos, à democratização do ensino e ao neoliberalismo, enunciando a construção de "uma escola para todos" e que valorize as diversidades humanas.

Assim, a proposta da inclusão potencializa o processo de normalização do sujeito "deficiente", ao promover a convergência de práticas educativas dos normais e dos anormais em um mesmo espaço e ao equalizar, dessa forma, os diferentes níveis de normalidade.

Dessa maneira, evidenciamos que os processos de normalização do sujeito "deficiente", como em um jogo de verdadeiro ou falso, deslocam-se entre espaços valorizados para a realização do ato educativo (instituição especializada - classes especiais das escolas comuns - classes comuns das escolas comuns) e entre discursos sobre a deficiência que ora 
responsabilizam o sujeito (discurso médico) ora a sociedade (discurso social), constituindo regimes de verdade descontínuos no processo de educação do sujeito "deficiente".

Feitas essas considerações, passaremos à elucidação dos regimes de verdade na educação do sujeito "rural", que, tal como a educação do sujeito "deficiente", são configurados em arenas de imbricações político-teóricas. Um passeio pela literatura especializada (WESCHENFELDER, 2003; FERNANDES; CERIOLI; CALDART, 2011; CALDART, 2011; MUNARIM, 2011; PIRES, 2012; ANTUNES-ROCHA, 2014; PORTES; SANTOS, 2014) permite-nos apontar duas "políticas gerais da verdade" (FOUCAULT, 2010b) na educação do sujeito "rural": a educação rural e a educação no/do campo.

A educação rural é permeada por significações ambíguas, marcadas pelo tensionamento entre o rural e o urbano, sendo que as primeiras ações de implantação de escolas no meio rural deram-se, no Brasil, no início e em meados do século XX. O desenvolvimento da educação rural atrelou-se ao movimento do "ruralismo pedagógico" (PIRES, 2012; ANTUNES-ROCHA, 2014; PORTES; SANTOS, 2014), que via na educação do sujeito "rural" uma possibilidade de conter o êxodo rural das populações pobres do campo. Nesse sentido, a educação rural compreendia um conjunto de enunciados relacionados à mudança dos costumes agrícolas, vistos como atrasados, ao preparo para o trabalho no campo e à elevação da produção agrícola (PORTES; SANTOS, 2014).

Caracterizada como uma educação feita para o sujeito "rural" (CALDART, 2011), a educação rural foi pensada por agentes oficiais, "sem a participação da população rural, esta que, analisada sempre pelo ângulo da carência e da decadência, deveria ser guiada, pois seria incapaz de pensar ou participar de decisões sobre o seu destino" (PORTES; SANTOS, 2014, p. 64).

Assim, a educação rural funcionou como objeto de governamento dos sujeitos "rurais", visando modernizá-los diante do processo de industrialização e progresso. Em outras palavras, conforme Weschenfelder (2003, p. 33), os enunciados sobre a educação rural são parte de uma estratégia maior - a modernização do campo - por meio de um objetivo estratégico: realizar a "mudança na mentalidade agrícola".

om o fortalecimento e a atuação dos movimentos sociais do campo, sobretudo o Movimento dos Trabalhadores Rurais Sem Terra (MST), nas últimas décadas do século XX, a educação do sujeito "rural" passa a ser demarcada por outras perspectivas políticas, teóricas e pedagógicas que buscam, explicitamente, romper com a concepção de educação rural (MUNARIM, 2011).

No bojo dessas lutas pela constituição da hegemonia na educação do sujeito "rural", um novo regime de verdade passa a ser veiculado no Movimento Por Uma Educação do Campo: a educação no/do campo - "no: o povo tem direito a ser educado no lugar onde vive; do: o povo tem o direito a uma educação pensada desde o seu lugar e com a sua participação, vinculada à sua cultura e às suas necessidades humanas e sociais" (CALDART, 2011, p. 149150, grifos da autora).

O uso do termo campo em detrimento da palavra rural integra um jogo político de significações, lutas e resistências: retoma o conceito de camponês, já que seu "significado é extraordinariamente genérico e representa uma diversidade de sujeitos", enfatizando o 
"sentido atual do trabalho camponês e das lutas sociais e culturais dos grupos que hoje tentam garantir a sobrevivência deste trabalho" (FERNANDES; CERIOLI; CALDART, 2011, p. 25). Desta feita, a categoria "camponês" funciona como uma identidade fundacional, a partir da qual derivam as demais identidades das populações rurais.

Os enunciados que constituem a educação no/do campo enfatizam, de um modo geral, sua caracterização, em oposição à educação rural, como uma educação feita com e pelos sujeitos do campo, e não apenas para o meio rural; uma educação que possui estreita relação entre a terra, o trabalho e a produção de suas existências (CALDART, 2011; MURARIM, 2011). Ademais, salientam a valorização das diversas culturas e identidades do campo, que se agrupam em uma "identidade comum: somos um só povo; somos parte do povo brasileiro que vive no campo e que historicamente tem sido vítima da opressão e da discriminação", sendo que a "nossa divisão em nome das diferenças somente interessa a quem nos oprime" (CALDART, 2011, p. 153-154).

A análise desses enunciados leva-nos a tecer duas considerações acerca do processo de normalização dos sujeitos "rurais": a) a participação de representantes desses sujeitos na elaboração de uma educação no/do campo não blinda a educação escolar dos sujeitos "rurais" de ações de controle socioinstitucional e regulação estatal, apenas "potencializam transformações das próprias estruturas de relação em que se sujeitam e, ambivalentemente, se tornam sujeitos" (FLEURI, 2006, p. 513); b) se, de um lado, as múltiplas identidades dos sujeitos do campo podem desagregar a unidade do movimento de educação no/do campo na luta contra "os opressores", por outro lado, essa multiplicidade pode dificultar o esquadrinhamento desses sujeitos e potencializar outras formas de ser, agir e pensar, ampliando, dessa maneira, as estratégias de resistências, de contracondutas e de recusas.

Mesmo assim, ante o exposto, apontamos deslocamentos nos regimes de verdade da educação do sujeito "rural", que transitam de um movimento educativo feito para a um movimento educativo feito com e por sujeitos "rurais" e, em decorrência disso, de uma política tida como colonizadora a uma política de afirmação da diversidade, dos costumes, dos valores e dos princípios dos sujeitos do campo.

Em vista disso, nesse momento, podemos tecer algumas aproximações entre os regimes de verdade vigentes na educação do sujeito "deficiente" e na educação do sujeito "rural": tanto a inclusão como a educação no/do campo circunscrevem-se no rol das lutas sociais dos sujeitos "deficientes" e "rurais" das últimas décadas do século XX, entrando em evidência principalmente a partir da década de 1990. Além disso, estas resultam da compreensão da educação enquanto um direito humano e a consequente busca por sua universalização. Por fim, ambas configuram-se, ao delimitar seu alcance e seus sujeitos, como políticas da diversidade, veiculando afirmativamente a condição de seus destinatários.

Entretanto, precisamos problematizar que os discursos atuais da inclusão escolar e da educação no/do campo, que têm funcionado como "verdadeiros" para a educação do sujeito "deficiente" e do sujeito "rural", não surgiram de um vazio transcendental, mas foram produzidos nas relações de poder-saber com outros discursos, estabelecendo cruzamentos, aproximações e distanciamentos. 
Nesse sentido, Bueno (2008) e Mendes (2006) têm questionado, no cenário da educação do sujeito "deficiente", o discurso da inclusão escolar como superação do da integração. Por sua vez, Portes e Santos (2014, p. 61-62) apontam que, no contexto da educação do sujeito "rural", as fronteiras entre o discurso da educação rural e o da educação no/do campo, "na prática, são menos visíveis do que aquelas fronteiras estabelecidas pelas discussões políticas e pelos discursos e construções teóricas acerca de uma e de outra educação".

De qualquer forma, compreendemos que a educação do sujeito "deficiente" e a educação do sujeito "rural" funcionam como mecanismos para identificar e normalizar as anomalias do sistema educacional geral. Dessa maneira, buscam tornar os sujeitos "deficientes" e "rurais" em corpos dóceis e úteis e, simultaneamente, controlar os eventos fortuitos e os riscos sociais que essas populações podem ocasionar.

Contudo, cumpre mencionarmos que, enquanto funcionamento do poder, a norma não pode ser descrita somente em termos negativos (reprime, recalca, exclui, esconde, etc.); isso porque o poder produz: objetos, rituais da verdade, saberes, sujeitos, resistências e subversões (FOUCAULT, 2010d).

Assim, nas relações de poder são produzidos os conhecimentos sobre a educação do sujeito "deficiente" e a educação do sujeito "rural", compreendidas como estratégias de um objetivo mais amplo, que é a normalização destes. Portanto, trataremos, na sequência, dos dispositivos que oficializam, no plano institucional e estatal, os regimes de verdade atuais da educação do sujeito "deficiente" e a educação do sujeito "rural", que são consideradas no conjunto das políticas educacionais da diversidade ${ }^{5}$.

Nessa conjuntura, alertamos que as políticas da diversidade estabelecem uma compreensão estereotípica, essencialista, rígida, hierarquizante, normalizadora dos sujeitos, enquadrando as identidades em unidades preestabelecidas e estáticas. Conforme Skliar (2002), essas políticas produzem uma diversidade que apenas se nota e com a qual se vibra, não indagando os processos discursivos e não discursivos de produção do "diferente".

Destarte, a ideia de homogeneização dos sujeitos "deficientes" e "rurais" no cenário das políticas da diversidade acaba por silenciar as múltiplas diferenças produzidas neste e subvertidas por estes sujeitos, invisibilizando-as e naturalizando-as sob o signo de um diverso genérico e unificador.

\section{A Educação Especial nos Dispositivos Educacionais Brasileiros}

A Constituição Federal de 1988 trata explicitamente da educação do sujeito "deficiente" no inciso III do Artigo 208, dispondo que o Estado deve garantir "atendimento educacional especializado aos portadores de deficiência preferencialmente na rede regular de ensino" (BRASIL, 1988).

Desde então, conforme Mendes e Malheiro (2012), o conceito de Atendimento Educacional Especializado (AEE) vem sendo apresentado com diversos sentidos nos documentos político-normativos: ora como antônimo de Educação Especial (para demarcar a preferência de matrículas nas classes comuns em detrimento das classes e escolas 
especiais), ora como sinônimo de Educação Especial (como é o caso da Lei de Diretrizes e Bases da Educação Nacional (LDB), de 1996), ora como um serviço de apoio à escolarização na classe comum (que é o sentido que passou a predominar nos documentos a partir de meados dos anos 2000).

A LDB trata da Educação Especial em um capítulo próprio (Capítulo V), definindo-a, em seu Artigo 58, como a "modalidade de educação escolar oferecida preferencialmente na rede regular de ensino, para educandos com deficiência, transtornos globais do desenvolvimento e altas habilidades ou superdotação"6 (BRASIL, 1996).

Nozu (2013) enfatiza que o advérbio "preferencialmente", presente nos dispositivos supracitados da Constituição, de 1988, e da LDB, de 1996, funcionou como objeto de disputa entre os grupos de interesse, que lhe deram interpretações distintas: para alguns, o advérbio diz respeito à matrícula do público-alvo da Educação Especial nas escolas comuns do ensino regular (que deve ser preferencial, mas não exclusiva!); para outros, o preferencialmente refere-se não à matrícula, mas à oferta do AEE, que deve ser prestado, de preferência, nas escolas comuns do ensino regular.

Destacamos, ainda, que a LDB, dentre outras garantias, assegura, no Artigo 59, aos alunos público-alvo da Educação Especial "currículos, métodos, técnicas, recursos educativos e organização específicos, para atender às suas necessidades” (BRASIL, 1996). Em que pese o cuidado do dispositivo em destacar a atenção às necessidades do alunado da Educação Especial, cumpre-nos sinalizar que necessidade educacional especial não é sinônimo de deficiência: "não é uma característica homogênea fixa, de um grupo etiológico também supostamente homogêneo, e sim [...] a demanda de determinado aluno em relação a uma aprendizagem no contexto em que é vivida" (GLAT; BLANCO, 2009, p. 26, grifos das autoras). Nesse sentido, é preciso afastar a visão estática (MAZZOTTA, 2005), ainda hegemônica na Educação Especial, que vincula diretamente o sujeito da Educação Especial às necessidades educacionais especiais. Além disso, entendemos que, além das necessidades específicas que podem resultar da condição de deficiência, a atenção a outras necessidades contextuais e socioculturais devem ser observadas no processo de escolarização desses alunos.

Ao contrário da Constituição Federal, de 1988, e da LDB, de 1996, as Diretrizes Nacionais para a Educação Especial na Educação Básica (2001) suprimem o advérbio "preferencialmente" e sugerem a matrícula dos alunos da Educação Especial nas classes comuns do ensino regular. Esse documento enfatiza no Artigo $4^{\circ}$, inciso II, o papel da Educação Especial voltado à "busca da identidade própria de cada educando, o reconhecimento e a valorização das suas diferenças e potencialidades, bem como de suas necessidades educacionais especiais no processo de ensino e aprendizagem" (BRASIL, 2001).

Novamente, é preciso tensionar a fixidez que parece se instaurar na ideia de "identidade própria" e de "reconhecimento e valorização das diferenças": consideramos que as identidades de um sujeito são múltiplas e se intercalam de acordo com o processo de enunciação; ademais, mais que reconhecer e valorizar as diferenças, elas devem ser questionadas e colocadas sob suspeita. Em tempo, cumpre observarmos o silenciamento 
dessas Diretrizes quanto às escolas do campo que atendem os alunos público-alvo da Educação Especial.

Em 2008, a Política Nacional de Educação Especial na Perspectiva da Educação Inclusiva materializa o regime de verdade atual na educação do sujeito "deficiente", explicitando seu objetivo de assegurar o acesso, a participação e a aprendizagem do públicoalvo da Educação Especial nas classes comuns do ensino regular (BRASIL, 2008a).

Essa Política conceitua a Educação Especial como "modalidade de ensino que perpassa todos os níveis, etapas e modalidades, realiza o atendimento educacional especializado, disponibiliza os recursos e serviços e orienta quanto a sua utilização no processo de ensino e aprendizagem nas turmas comuns do ensino regular". Desta feita, demarca a atuação da Educação Especial para grupos determinados de sujeitos com deficiências, transtornos globais do desenvolvimento e altas habilidades/superdotação (BRASIL, 2008a).

Cabe aqui apontarmos que a definição do público-alvo da Educação Especial fundamenta-se em um essencialismo biológico, que toma o corpo desses sujeitos para definirem suas identidades. Isso porque, para Woordward (20014, p. 15), “o corpo é um dos locais envolvidos no estabelecimento das fronteiras que definem quem nós somos, servindo de fundamento para a identidade".

Assim, os sujeitos da Educação Especial, quando matriculados nas classes comuns das escolas regulares, têm sido encaminhados, quase que mecanicamente e sem uma avaliação adequada da existência e da definição de suas necessidades educacionais especiais, para o AEE (GLAT; PLETSCH, 2011; NOZU, 2013). Isso ilustra, mais uma vez, as representações que são construídas, de forma fixa, sobre a condição do público-alvo da Educação Especial, direcionando-os, irremediavelmente, para o AEE.

Da Política Nacional de Educação Especial na Perspectiva da Educação Inclusiva importa-nos frisar a previsão da interface entre a Educação Especial e a Educação do Campo, in verbis:

A interface da educação especial na educação indígena, do campo e quilombola deve assegurar que os recursos, serviços e atendimento educacional especializado estejam presentes nos projetos pedagógicos construídos com base nas diferenças socioculturais desses grupos (BRASIL, 2008 ${ }^{\mathrm{a}}$, p.17, grifos nossos).

Diante desse dispositivo, cabe-nos questionar como tem se dado a observância das "diferenças socioculturais" na elaboração da interface Educação Especial - Educação do Campo nos projetos pedagógicos e na dinâmica do "chão da escola". Em outras palavras, cumpre, na análise da política, verificar se a atuação da Educação Especial nas escolas do campo tem se atentado, quando da elaboração de estratégias e recursos pedagógicos, aos princípios, valores, culturas e especificidades dos alunos oriundos do campo ou se tão somente tem reproduzido um modelo de Educação Especial "urbanocêntrico" nas escolas do campo. E, mais que isso, cabe problematizarmos como essas diferenças socioculturais têm sido produzidas nos entre-lugares que se estabelecem entre a Educação Especial e outras modalidades de educação. 
Em tempo, vale destacar que o AEE - foco de atuação da atual política de Educação Especial - é definido "como o conjunto de atividades, recursos de acessibilidade e pedagógicos organizados institucional e continuamente" (BRASIL, 2011), que tem "como função identificar, elaborar e organizar recursos pedagógicos e de acessibilidade que eliminem as barreiras para a plena participação dos alunos, considerando suas necessidades específicas" (BRASIL, 2008 , p.16).

Ademais, o AEE deve ser ofertado no turno inverso ao da escolarização, na própria escola comum, em outra escola de ensino regular ou em centro especializado que realize tal serviço (BRASIL, 2009). Os dispositivos recomendam que esse atendimento não tenha caráter substitutivo às classes comuns (BRASIL, 2008a, 2009), buscando complementar a formação dos estudantes com deficiência e transtornos globais do desenvolvimento e suplementar a formação dos alunos com altas habilidades/superdotação (BRASIL, 2011). O parágrafo $2^{\circ}$ do Artigo $2^{\circ}$ do Decreto n. $.^{\circ} 7.611 / 2011$ alerta que

O atendimento educacional especializado deve integrar a proposta pedagógica da escola, envolver a participação da família para garantir pleno acesso e participação dos estudantes, atender às necessidades específicas das pessoas público-alvo da educação especial, e ser realizado em articulação com as demais políticas públicas (BRASIL, 2011).

As Diretrizes Operacionais para o AEE na Educação Básica (BRASIL, 2009) dispõem que esse serviço seja ofertado prioritariamente nas Salas de Recursos Multifuncionais (SRMs), definidas como "ambientes dotados de equipamentos, mobiliários e materiais didáticos e pedagógicos para a oferta do atendimento educacional especializado" (BRASIL, 2011).

Sem tardar, registramos que o Plano Nacional de Educação - PNE (2014-2024) trata, em sua Meta 4, sobre a universalização para o público-alvo da Educação Especial, na faixa etária dos 04 (quatro) aos 17 (dezessete) anos, à educação básica e ao AEE, preferencialmente na rede regular de ensino, assegurando um sistema educacional inclusivo (BRASIL, 2014). Uma das estratégias prioritárias dessa meta, acompanhando as ações governamentais da última década $^{7}$ para a área da Educação Especial, acena para a relação dessa modalidade de ensino com a Educação do Campo: "implantar, ao longo deste PNE, salas de recursos multifuncionais e fomentar a formação continuada de professores e professoras para o atendimento educacional especializado nas escolas urbanas, do campo, indígenas e de comunidades quilombolas" (BRASIL, 2014).

Pesquisadores da área da Educação Especial (BRUNO, 2012; MENDES; MALHEIRO, 2012; NOZU, 2013) têm apresentado críticas ao caráter redutor, simplista e instrumental do AEE ofertado no formato das SRMs.

Mendes e Malheiro (2012) entendem a política de AEE em SRMs como um tipo de "serviço tamanho único" que explicita uma simplificação dos serviços de apoio da Educação Especial e que não encontra, na literatura científica da área, sustentação em termos de efetividade. Por sua vez, Bruno (2012) compreende que este "modelo único" representa uma 
tática geral de governamentalidade que coloca em funcionamento a lógica do mercado e a instrumentalização da Educação Especial.

Recentemente, a Lei Brasileira de Inclusão da Pessoa com Deficiência (Estatuto da Pessoa com Deficiência), enfatiza, em seu Capítulo IV, o direito à educação da pessoa com deficiência, incumbindo, no Artigo 28, dentre outras responsabilidades, o poder público de: aprimorar os sistemas educacionais para garantir "condições de acesso, permanência, participação e aprendizagem, por meio da oferta de serviços e de recursos de acessibilidade que eliminem as barreiras e promovam a inclusão plena" (inciso II); institucionalizar o AEE junto aos projetos pedagógicos das escolas, bem como "os demais serviços e adaptações razoáveis, para atender às características dos estudantes com deficiência e garantir o seu pleno acesso ao currículo em condições de igualdade, promovendo a conquista e o exercício de sua autonomia" (inciso III); adotar "medidas de apoio que favoreçam o desenvolvimento dos aspectos linguísticos, culturais, vocacionais e profissionais, levando-se em conta o talento, a criatividade, as habilidades e os interesses do estudante com deficiência" (inciso IX) (BRASIL, 2015).

De um modo geral, a Lei de Inclusão reforça as especificidades das pessoas com deficiência e indica a eliminação das barreiras e a criação de estratégias para assegurar, em condições de igualdade, o gozo de direitos e a promoção da inclusão social e da cidadania da pessoa com deficiência.

A partir dos dispositivos elencados, podemos sintetizar a ordem do discurso da Educação Especial nos dispositivos educacionais brasileiros: a política em vigor, de perspectiva inclusiva, indica a matrícula dos alunos com deficiência, transtornos globais do desenvolvimento e altas habilidades/superdotação nas classes comuns do ensino regular, sendo ofertado, facultativamente e no contraturno, AEE, de forma complementar e suplementar, prioritariamente nos espaços das SRMs.

\section{A Educação do Campo nos Dispositivos Educacionais Brasileiros}

Ao contrário da educação do sujeito "deficiente", a educação do sujeito "rural" não foi expressamente mencionada na Constituição Federal de 1988. Assim, nesse silenciamento, a educação do sujeito "rural" "foi considerada como direito, mas um direito, ainda, inspirado no paradigma urbano" (PIRES, 2012, p. 90). A ênfase dada aos direitos do sujeito "rural" nesse documento recai na condição de produtor/trabalhador das áreas rurais. Entretanto, ao estabelecer, no Artigo 62 das Disposições Constitucionais Transitórias, a criação do Serviço Nacional de Aprendizagem Rural (SENAR), por meio de legislação específica, acena para a educação do sujeito "rural" e para a elaboração de políticas educacionais para o setor.

Se a educação do sujeito "deficiente" é tratada em capítulo próprio da LDB de 1996, o mesmo não acontece com a educação do sujeito "rural": apenas um artigo da referida legislação dispõe sobre a educação básica para a população rural. Trata-se do Artigo 28, que preconiza que os sistemas de ensino deverão atentar-se às peculiaridades da vida no campo e prever: conteúdos curriculares e metodologias apropriadas às necessidades e aos interesses 
dos alunos do campo; organização escolar própria, incluindo adequação do calendário escolar às fases do ciclo agrícola e às condições climáticas; adequação à natureza do trabalho no campo (BRASIL, 1996).

Nesse sentido, uma das estratégias de organização da Educação do Campo tem se dado no regime de alternância entre dois tempos-espaços distintos no processo formativo: um voltado às práticas no contexto escolar, denominado tempo-escola, e outro voltado às atividades de trabalho e estudo junto à família e à comunidade, chamado tempo-comunidade.

Para Lourdes Silva (2014), o regime de alternância permite uma conjugação da formação teórico-acadêmica com atividades no contexto da vida e do trabalho das populações do campo, buscando um diálogo com os saberes e a cultura local. Diante disso, a alternância é tida como uma "estratégia para abertura do mundo escolar à realidade de vida dos jovens, para flexibilização da organização do calendário escolar e adequação à vida no meio rural; para aplicação do conhecimento escolar na propriedade dos jovens; para realização de estágio de vivência" (SILVA, L., 2014, p. 107).

Queiroz (2004) e Lourdes Silva (2014) indicam três tipos de alternância: a) alternância justapositiva - quando há mera sucessão do tempo-escola e do tempo-comunidade, sem uma relação entre ambos; b) alternância associativa - quando há uma relação entre a atividade escolar e a atividade profissional, organizada, contudo, como uma simples adição; c) alternância integrativa real ou copulativa - quando há uma sinergia, uma retroalimentação, uma compenetração efetiva entre os tempos formativos escolares e os socioprofissionais, superando a visão dicotômica entre tempo-espaço teórico e tempo-espaço prático.

As Diretrizes Operacionais para a Educação Básica nas Escolas do Campo, instituídas por meio da Resolução n. ${ }^{\circ}$ 1, de 03 de abril de 2002, constituem-se como um conjunto de princípios e procedimentos para adequar o projeto institucional das escolas do campo às diretrizes curriculares nacionais referentes a cada etapa da Educação Básica, bem como das modalidades de ensino, dentre elas, a Educação Especial (BRASIL, 2002).

Para Munarim (2011), a definição da Educação do Campo não é "fixa" nem "fechada num conjunto de palavras", mas está em um movimento de construção teórica. Por isso, para Arroyo, Caldart e Molina (2011, p. 12-13), a Educação do Campo traz "uma grande lição e um grande desafio para o pensamento educacional: entender os processos educativos na diversidade de dimensões que os constituem como processos sociais, políticos e culturais; formadores do ser humano e da própria sociedade".

Por conseguinte, essas Diretrizes salientam que as escolas do campo devem dar atenção ao seu entorno, aos contextos nos quais estão inseridas, de modo que contemplem, em suas propostas pedagógicas, "a diversidade do campo em todos os seus aspectos: sociais, culturais, políticos, econômicos, de gênero, geração e etnia" (Artigo $2^{\circ}$ ) (BRASIL, 2002). Salientamos que, por um ponto de vista, as Diretrizes apontam para a articulação entre Educação do Campo e Educação Especial; por outro, quando enunciam "todos os aspectos" da diversidade do campo, silenciam quanto às peculiaridades do público-alvo da Educação Especial.

A Resolução CNE/CEB n. ${ }^{\circ}$ 2/2008, que estabelece diretrizes complementares, normas e princípios para o desenvolvimento de políticas públicas de atendimento da Educação Básica do Campo, dispõe, em seu Artigo $1^{\circ}$, que a Educação do Campo "destina-se ao atendimento 
às populações rurais em suas mais variadas formas de produção da vida" (BRASIL, 2008b). Com o intuito de acenar para a relação entre Educação do Campo e Educação Especial, enfatizamos o parágrafo $5^{\circ}$, do mesmo Artigo $1^{\circ}$, o qual indica a necessidade dos sistemas de ensino adotarem providências para que os alunos da Educação Especial, que vivem no campo, tenham acesso à educação básica, preferencialmente em escolas comuns da rede regular de ensino (BRASIL, 2008b).

O Decreto n. ${ }^{\circ}$ 7.352, de 04 de novembro de 2010, dispõe sobre a Política de Educação do Campo e o Programa Nacional de Educação na Reforma Agrária (PRONERA), considerando como público-alvo da Educação do Campo:

[...] os agricultores familiares, os extrativistas, os pescadores artesanais, os ribeirinhos, os assentados e acampados da reforma agrária, os trabalhadores assalariados rurais, os quilombolas, os caiçaras, os povos da floresta, os caboclos e outros que produzam suas condições materiais de existência a partir do trabalho no meio rural (BRASIL, 2010).

A partir do que foi enunciado, temos indícios de que a definição do público-alvo da Educação do Campo sustenta-se em um essencialismo cultural, tomando por base o compartilhamento de algumas práticas sociais e culturais no meio rural e, mais que isso, um histórico comum de negação e inferiorização (WOODWARD, 2014).

Entendemos, assim, que embora algumas lutas sejam transversais aos sujeitos do campo, suas identidades são múltiplas, forjadas nas relações de poder-resistências e tomadas, contingencialmente, para atuação performativa nas encenações sociais. Se a definição da Educação do Campo não é fixa (MUNARIM, 2011), compreendemos que as identidades de seus sujeitos também não o são.

Quanto à definição de escola do campo, pode ser tanto aquela situada em área rural, conforme classificação do Instituto Brasileiro de Geografia e Estatística (IBGE), como a situada em área urbana, desde que atenda predominantemente as populações do campo (BRASIL, 2010). Em outras palavras, "a identidade da escola do campo é definida não exclusivamente pela sua situação espacial não urbana, mas prioritariamente pela cultura, relações sociais, ambientais e de trabalho dos sujeitos do campo que a frequentam" (MUNARIM, 2011, p. 12).

Entretanto, o Movimento Por Uma Educação do Campo tem defendido uma educação no e do campo:

[...] "no campo", porque o povo tem direito de ser educado preferentemente onde vive, isto é, sem ter que submeter-se forçosamente a longos e cansativos transportes para escolas situadas em realidades, mormente, urbanas; "do campo", porque o povo tem o direito a uma educação pensada desde o seu lugar e com a sua participação, vinculada a sua cultura e as suas necessidades humanas e sociais. Trata-se, portanto, de uma educação dos e não para os sujeitos do campo, que combine pedagogias de maneira a fazer uma educação que forme e cultive 
identidades, autoestima, valores, memórias, saberes, sabedoria (MUNARIM, 2011, p. 12).

Assim, para Fernandes, Cerioli e Caldart (2011, p. 23, grifos dos autores), a Educação do Campo precisa ser uma "educação específica e diferenciada, isto é, alternativa. Mas, sobretudo, deve ser educação, no sentido amplo de processo de formação humana, que constrói referências culturais e políticas para a intervenção das pessoas e dos sujeitos sociais na realidade".

Para tanto, os recursos didáticos, pedagógicos e culturais voltados à Educação do Campo devem atender às especificidades dos seus sujeitos e trabalhar com conteúdos contextualizados aos saberes das comunidades em diálogo com os saberes acadêmicos (BRASIL, 2010). Nesse processo, o projeto político-pedagógico constitui-se como instrumento de enunciação dessa proposta, devendo partir de uma análise contextual da escola e das populações do campo por ela atendidas.

Pires (2012) sugere que os projetos político-pedagógico das escolas do campo se pautem nos eixos a seguir: relação entre educação e trabalho, teoria e prática social; ação investigativa, questionadora e criativa; relações entre educação, cultura, política e economia; trabalho coletivo, a construção da autonomia dos coletivos de docentes e discentes; gestão democrática.

Em síntese, os dispositivos da Educação do Campo indicam uma educação construída pelos interesses e pelas necessidades das diversas populações do campo, entendidas amplamente como aquelas que produzem sua existência da e na terra. Logo, defendem a criação de projetos pedagógicos que contemplem, em seus currículos e metodologias, os valores, os princípios, as práticas e as culturas dos sujeitos que vivem no e do campo, assim como uma flexibilização de tempo-espaço na organização escolar para os processos formativos.

Contudo, um dos entraves para a construção da Educação do Campo, tal como enuncia Antunes-Rocha (2014, p. 29), "diz respeito à superação das representações depreciativas que temos dos sujeitos, do trabalho, do espaço, da cultura e dos modos de produzir a vida no campo". Além disso, a Educação do Campo é marcada pela precariedade: falta de infraestrutura necessária; escolas distantes do lugar ondem vivem as populações do campo; merenda escolar insuficiente; currículos e calendários alheios à realidade do campo; salas multisseriadas; material didático com temas que não se atentam à vida no campo; permanência dos altos índices de analfabetismo, reprovação e evasão; formação docente deficitária (FERNANDES; CERIOLI; CALDART, 2011; PIRES, 2012; PORTES; SANTOS, 2014). 


\section{Interfaces da Educação Especial e da Educação do Campo: rumo às políticas das diferenças}

A política é um campo de lutas complexas, travadas no tempo-espaço, envolvendo diversos grupos de interesse que apresentam suas demandas e reivindicações para direcionar o acesso aos bens públicos materiais e imateriais. Esta concepção de política, denominada de pluralista, enfatiza a atuação dos múltiplos grupos de pressão e de interesse na elaboração das políticas públicas (AZEVEDO, 1997).

Nessa perspectiva, entendemos que tanto as atuais políticas de Educação Especial quanto as de Educação do Campo foram processadas pelo sistema político em um complexo feixe de influências, relações e negociações com, respectivamente, os movimentos sociais das pessoas com deficiência e os movimentos sociais do campo.

Costuradas pela agulha da marginalidade, algumas aproximações entre Educação Especial e Educação do Campo podem ser tecidas: ambas sofrem descaso na seara das ações governamentais (CAIADO, 2010; CAIADO; MELETTI, 2011); são historicamente atingidas por práticas assistencialistas (MAZZOTTA, 2005; CALDART, 2011); tem seus públicosalvos inferiorizados, estigmatizados e estereotipados (CAIADO, 2010; FERNANDES; CERIOLI; CALDART, 2011; SANTOMÉ, 2013); encontram-se em situação de invisibilidade (MARCOCCIA, 2011; ANJOS, 2016); são vozes ausentes na seleção da cultura e do currículo escolar (SANTOMÉ, 2013).

Dado esse cenário, algumas lutas dos sujeitos da Educação Especial e da Educação do Campo podem ser caracterizadas pela transversalidade: ambas resultam de movimentos sociais contra os múltiplos processos de exclusão social; evidenciam o reconhecimento da vida das pessoas e das suas necessidades básicas; empreendem resistências contra as formas de assujeitamento; buscam o empoderamento e a afirmação positiva de seus sujeitos.

Com Foucault (2010f), podemos sintetizar essas lutas transversais dos sujeitos "deficientes" e dos sujeitos "rurais" enquanto oposição às formas de dominação (social, cultural, biológica) de exploração (que separam os indivíduos daquilo que produzem), e de sujeição (contra aquilo que liga o indivíduo a si mesmo e o submete, dessa maneira, aos outros).

Santos (2010, p. 280) nos estimula a pensar nas lutas desses sujeitos a partir de dois sistemas de pertença hierarquizada: o da desigualdade e o da exclusão. $\mathrm{O}$ de desigualdade, fundado no aspecto socioeconômico, é operacionalizado por um sistema hierárquico de integração social subordinada, portanto, "quem está em baixo está dentro e sua presença é indispensável". O sistema de exclusão, por sua vez, fundamenta-se no aspecto sociocultural e, apesar de também ser hierarquizado, opera pelo princípio da segregação: "quem está embaixo, está fora".

Assim, entendemos que tanto os sujeitos "deficientes" como os "rurais" são inseridos nos sistemas de desigualdade e de exclusão, que, na prática, se intercalam e formam combinações complexas. Para Anjos (2016), esses sujeitos são inseridos em um sistema "bilateral" de desigualdade e exclusão, produzindo, desse modo, silenciamentos e invisibilizações. 
Diante da desigualdade e da exclusão produzidos pelo sistema capitalista, as lutas sociais passaram a reivindicar do Estado "políticas redistributivas e formas menos extremas de exclusão" (SANTOS, 2010, p. 312). Assim, a gestão controlada desses sistemas de pertença hierarquizada não foi uma iniciativa do Estado capitalista, mas o produto das pressões sociais.

Nesse processo político de múltiplas negociações, consideramos, por um lado, que, "por diferentes caminhos, os movimentos sociais organizados na luta por melhores condições de vida, as pessoas com deficiência e os trabalhadores do campo, têm conquistado espaço na legislação; têm, portanto, conquistado instrumentos jurídicos de luta" (CAIADO; GONÇALVES, 2013, p. 182). Por outro lado, compreendemos que a gestão dos sistemas de desigualdades e de exclusão constitui-se em estratégia biopolítica de apaziguamento e regulação social.

De todo jeito, essas questões têm sido tratadas no contexto das políticas da diversidade. Estas buscam atender a determinadas demandas "das diversidades", articulando-se aos princípios democráticos, aos direitos humanos de populações marginalizadas, às influências neoliberais no campo das políticas sociais, às estratégias biorregulamentadoras e às reivindicações dos diversos grupos que requerem voz e vez nas arenas decisórias dos espaços públicos.

Nas últimas décadas, as políticas educacionais brasileiras têm sido convocadas a atender ao desafio da diversidade e adotar, simultaneamente, medidas de universalização e de focalização para o alcance do direito à educação de populações vulneráveis e marginalizadas sócio, cultural e economicamente.

As políticas universalistas propõem uma educação igualitária aos estudantes, sem distinções étnico-raciais, sociais, de religião, de gênero, de crença e de capacidade, visando ao acesso, à permanência e ao sucesso nas etapas da educação básica. Por sua vez, dada a insuficiência das políticas universalistas, as políticas focalizadas, como base no princípio da equidade, afirmam-se como proposta para efetivação do direito à educação de "determinados grupos marcados por uma diferença específica", buscando "dar mais a quem mais precisa" (CURY, 2005, p. 15).

Não se trata somente de caminhar rumo ao direito universal à educação, mas de, nessa trajetória, inserir na pauta política, as demandas pontuais de determinados grupos que lutam pelo direito a uma educação diferenciada. Nesse sentido, concordamos com Laclau (2011, p. 57), quando aponta que "o universal é o símbolo de uma plenitude ausente, e o particular existe apenas no movimento contraditório da afirmação simultânea de uma identidade diferencial e seu cancelamento por meio de sua inclusão num meio não diferencial".

A defesa desse ideal resulta da combinação do direito à igualdade e do direito à diferença. Se as políticas universais visam atingir a todos igualmente, em contrapartida, as políticas focalizadas buscam suprir as lacunas deixadas por aquelas e atender as peculiaridades de determinadas populações (CURY, 2005).

Entretanto, salientamos que "a relação entre o direito à igualdade de todos e o direito à equidade, em respeito à diferença, no eixo do dever do Estado e do direito do cidadão não é uma relação simples" (CURY, 2005, p. 16). Para tanto, é preciso que "se desconstrua a oposição binária igualdade/diferença como única via possível, chamando a atenção para o 
constante trabalho da diferença dentro da diferença" (FLEURI, 2006, p. 500, grifos do autor).

Santos (2010) nos adverte acerca dos efeitos dos essencialismos da igualdade e da diferença: o primeiro, situado no eixo socioeconômico, pode gerar desigualdade, ao passo que o segundo, situado no eixo cultural, pode gerar exclusão. O essencialismo da igualdade descaracteriza as diferenças e as identidades, absolutizando uma delas e desprezando as demais. Já o essencialismo da diferença atua pela intensificação abstrata de várias diferenças ou identidades, perdendo de vista os movimentos desiguais entre elas.

Dessa maneira, "quer um, quer outro processo permitem a aplicação de critérios abstractos de normalização, sempre baseados numa diferença que tem poder social para negar todas as demais ou para as declarar incomparáveis e, portanto, inassimiláveis" (SANTOS, 2010, p. 283-284). Isso posto, se o essencialismo da igualdade fomenta a desigualdade e a exclusão pelo excesso de semelhança, o essencialismo da diferença fomenta a desigualdade e a exclusão pelo excesso de diferença. Portanto, Santos (2010, p. 313) destaca a necessidade de um "meta-direito intercultural" que presida as relações entre igualdade e diferença: "temos o direito a ser iguais sempre que a diferença nos inferioriza; temos o direito de ser diferentes sempre que a igualdade nos descaracteriza".

Diante desse quadro, evidenciamos a armadilha essencialista das políticas focalizadas da diversidade: ao promover, equitativamente, o empoderamento de determinados sujeitos, estes acabam, no processo, sendo marcados por dadas diferenças e tendo suas identidades fixadas e naturalizadas.

Para Woodward (2014, p. 13, grifo da autora), "com frequência, a identidade envolve reivindicações essencialistas sobre quem pertence e quem não pertence a um determinado grupo identitário, nas quais a identidade é vista como fixa e imutável". Dessarte, a perspectiva essencialista é tomada como um conjunto autêntico, cristalino, de características compartilhadas por todos os sujeitos do grupo e que não se alteram ao longo do tempo (WOODWARD, 2014).

Assim, se de um lado a definição do público-alvo da Educação Especial e da Educação do Campo torna-se um importante fator identitário de mobilização política, delimitando os sujeitos a serem alcançados por políticas diferenciadas, do outro, acaba por traduzir políticas essencialistas que circunscrevem seu âmbito de atuação. Isso ocorre pois "afirmar a identidade significa demarcar fronteiras, significa fazer distinções entre o que fica dentro e o que fica fora. [...] Essa demarcação de fronteiras, essa separação e distinção, supõem e, ao mesmo tempo, afirmam e reafirmam relações de poder" (SILVA, T., 2014, p. 82).

Conforme Bhabha (2013), as políticas da diversidade referem-se a um objeto de conhecimento empírico, reconhecendo conteúdos ou costumes culturais pré-dados. Nesse sentido, a política de Educação Especial acaba por fixar as identidades de seus sujeitos nos aspectos biológicos, ao passo que a política de Educação do Campo parte de justificativas históricas e culturais para essencializar as identidades de seus sujeitos. De acordo com Woordward (2014, p. 38, grifo da autora), "o essencialismo pode, assim, ser biológico e natural, ou histórico e cultural. De qualquer modo, o que eles têm em comum é uma concepção unificada de identidade". 
Além disso, entendemos que a oposição binária entre aluno da Educação Especial x aluno da Educação Comum e entre aluno da Educação do Campo x aluno da Educação Urbana obscurece as diferenças dentro de cada um desses grupos quanto a comportamentos, desejos, aprendizagens, necessidades, experiências, etc. Ou seja, a ideia de homogeneização desses grupos mascara e silencia as diferenças dentro das diferenças, invisibilizando-as.

Portanto, as políticas da diversidade enquadram e sujeitam as identidades e as diferenças a partir de categorias já estabelecidas, deixando de questionar as relações de poder e os processos de diferenciação que produzem as identidades e as diferenças. Nessa mecânica, é operacionalizada a

[...] pedagogia da diversidade como pluralização do "eu mesmo" e de "o mesmo"; uma pedagogia que hospeda, que abriga; mas uma pedagogia a qual não importa quem é seu hóspede, mas que se interessa pela própria estética do hospedar, do alojar. Uma pedagogia que reúne, ao mesmo tempo, a hospitalidade e a hostilidade em relação ao outro. Que anuncia sua generosidade e esconde sua violência de ordem. Uma pedagogia que não se preocupa (e que se aborrece) com a identidade do outro, quando não repete (até a exaustão) somente a ipseidade do "eu" (SKLIAR, 2002, p. 12).

Dito de outra maneira, as políticas da diversidade - ao cristalizar, essencializar e naturalizar determinadas identidades - funcionam mediante oposições binárias, travestindose, sob a égide do multiculturalismo, em enunciados que contemplam a polidez e a tolerância e que promovem uma celebração cínica das diferenças, mas que não permitem ir além do "eu" e do "outro" e produzir, desse modo, o inclassificável e o indefinível.

Talvez, tal como nos ensina Foucault (2010f, p. 283), enquanto estratégia de subversão e resistência aos processos normalizadores que nos assujeitam, precisássemos imaginar e construir modos de ser para além da mesmice, e, assim, não "descobrir o que somos, mas recusar o que somos".

\section{Algumas Considerações}

Ante o exposto, entendemos que a compreensão das diferenças requer um olhar mais complexo, deslizante e híbrido, que supere as lógicas fundadas nos binarismos e as perspectivas essencialistas, ou seja, uma compreensão que problematize as identidades e as diferenças e avance para além das políticas da diversidade.

Precisamos, portanto, para tratar das articulações Educação Especial - Educação do Campo, deslocar a ênfase das políticas da diversidade para as políticas das diferenças. Embora diversidade e diferença pareçam termos similares, com usos e caráter de representação soando como idênticos, seus usos parecem ser os mesmos, seu caráter de representação da alteridade parece idêntico, "entre a diversidade e a diferença existe um 
abismo insondável, uma distância política, poética e filosoficamente opressora" (SKLIAR, 2002, p. 4).

Na construção desse regime de verdade, Tomaz Silva (2014) indica as distâncias entre a diferença e a diversidade: esta é estática, é um estado, é estéril; aquela é processo, construção, ação. A diversidade limita-se ao existente; a diferença permite a emergência do novo. A diversidade é um dado - da natureza ou da cultura; a diferença é um movimento.

Contrapondo-se às políticas da diversidade, as políticas das diferenças questionam a produção da identidade e da diferença, tomando-as como relações de poder, subvertem a estabilidade das categorias biológicas e culturais, construídas a partir de oposições binárias, e, ainda, apontam as diferenças dentro das diferenças como uma alternativa às perspectivas essencialistas.

Nas políticas da diferença, a identidade não é um conceito essencialista, mas um conceito estratégico, posicional, fragmentado e fraturado, que é multiplamente construído "ao longo de discursos, práticas e posições que podem cruzar ou ser antagônicos" (HALL, 2014, p. 108). Isso porque o sujeito assume identidades diferentes (por vezes, contraditórias) em diferentes momentos; identidades que não se organizam em torno de um "eu" coerente, mas que empurram "em diferentes direções, de tal modo que nossas identificações estão sendo continuamente deslocadas" (HALL, 2011, p. 13).

Nesse sentido, para Hall (2014), a identidade é um conceito que opera "sob rasura" e que se torna fluido de acordo com os processos de enunciação do sujeito. Isso porque, ao sermos posicionados em diferentes contextos que nos impõem certas expectativas e restrições sociais, representamo-nos de maneiras distintas e deslizantes. Assim, "as identidades são, pois, pontos de apego temporário às posições-de-sujeito que as práticas discursivas constroem para nós" (HALL, 2014, p. 112).

Conforme Bhabha (2013), nas políticas das diferenças, há um deslocamento do sujeito da cultura para o sujeito da enunciação, já que a diferença cultural é um processo de enunciação da cultura. Por sua vez, Canclini (2013) desloca a ênfase da identidade para as hibridizações interculturais.

Importa-nos salientar que as políticas das diferenças - com seus múltiplos e transitórios significados e com suas potências criativas e promissoras - possibilitam a emergência de espaços intersticiais com enunciações de diferentes sujeitos e de múltiplas identidades socioculturais, de modo a tornar possível o processo de hibridização.

Dessa maneira, "o que é teoricamente inovador e politicamente crucial é a necessidade de passar além das narrativas de subjetividades originárias e iniciais e de focalizar aqueles momentos ou processos que são produzidos na articulação de diferenças culturais" (BHABHA, 2013, p. 20). Logo, cabe-nos situar, para além dos espaços fixos, em terrenos movediços e analisar, nos tempos-espaços culturais, as figuras complexas de diferença e identidade produzidas, em um processo ativo e contingente, pelas práticas discursivas e não discursivas.

Isso porque acreditamos que a análise das interfaces Educação Especial e Educação do Campo necessita de uma perspectiva epistemológica que possibilite problematizar os sujeitos, os tempos e os espaços demarcados nessas propostas educacionais, pré-definidos 
nos dispositivos político-normativos, e nos levar a um cenário intermédio, heterotópico, fronteiriço, capaz de (re)criar as dimensões do híbrido, do complexo, do imprevisível diante de práticas educativas distintas combinadas em condições contingenciais. Nesse sentido, "educar significa introduzir a cunha da diferença em um mundo que sem ela se limitaria a reproduzir o mesmo e o idêntico, um mundo parado, um mundo morto" (SILVA, T., 2014, p. 101).

Diante dessas premissas, a nossa compreensão da interface sinaliza para os trânsitos de sujeitos híbridos por tempos e espaços intersticiais que se cruzam "entre as faces" da Educação Especial e da Educação do Campo. Não há, nessa perspectiva, a materialização de um único espaço, um único tempo e um único sujeito da interface; "entre as faces" da Educação Especial e da Educação do Campo temos sujeitos, espaços e tempos educativos múltiplos. Trata-se de movimentos intervalares de entrada, de saída e de dispersão dos sujeitos nos "entre" tempos e espaços da Educação Especial e da Educação do Campo.

Nesse caminhar, urge às práticas educativas "reconhecer o diferente e elaborar as tensões das diferenças" (CANCLINI, 2013, p. XXVI), de modo a acenar para as diferenças dentro das diferenças e tomar as interfaces Educação Especial - Educação do Campo como temposespaços de negociações e de traduções culturais, nos quais identidades e diferenças são produzidas e posicionadas discursivamente nas relações de saber-poder presentes tanto nas políticas educacionais quanto no cotidiano escolar.

\section{Notas}

1. Vale destacar que, para Foucault (2010b, p. 12), a verdade não é algo transcendental, ao contrário, "a verdade é deste mundo; ela é produzida nele graças a múltiplas coerções e nele produz efeitos regulamentadores de poder".

2. No modelo médico, a deficiência é tomada tão-somente a partir de sua causa orgânico-biológica, ou seja, focaliza apenas os elementos intrínsecos ao sujeito.

3. São proclamadas, no âmbito internacional, na década de 1970: a Declaração dos Direitos das Pessoas com Retardo Mental (1971), Declaração dos Direitos das Pessoas Deficientes (1975) e a Resolução da Assembleia Geral da Organização das Nações Unidas n. ${ }^{\circ}$ 31/123, em 1976, declarando o ano de 1981 como o Ano Internacional das Pessoas Deficientes.

4. No modelo social, a deficiência é considerada a partir de uma multiplicidade de causas, para além dos orgânicobiológicos, enfatizando os elementos sociais e ambientais, ou seja, elementos extrínsecos ao sujeito.

5. Atualmente, as políticas de Educação Especial e de Educação do Campo estão vinculadas, no aparato estatal, à Secretaria de Educação Continuada, Alfabetização, Diversidade e Inclusão (SECADI) (MEC, 2019).

6. Redação dada pela Lei n. ${ }^{\circ}$ 12.796, de 2013. Antes dessa lei, a LDB/1996 indicava que o público-alvo da Educação Especial eram os "educandos portadores de necessidades especiais".

7. No âmbito do Plano de Desenvolvimento da Educação (PDE), desde 2007, por meio do Programa de Implantação de Salas de Recursos Multifuncionais, o Ministério da Educação tem lançado editais para receber e selecionar propostas para o financiamento de salas de recursos multifuncionais do Tipo 1 e do Tipo 2, conforme as demandas das redes registradas no Censo Escolar. As salas classificadas como Tipo 1 dispõem de equipamentos, mobiliário e materiais que possibilitam o atendimento dos alunos público-alvo da educação especial, com exceção dos alunos com deficiência visual (cegueira e baixa visão). As salas do Tipo 2 possuem, além dos equipamentos previstos nas do Tipo 1, recursos específicos para o atendimento dos alunos com deficiência visual, possibilitando também o atendimento dos demais sujeitos da educação especial. 


\section{Referências}

ANJOS, Christiano Felix dos. Realidades em contato: construindo uma interface entre Educação Especial e Educação do Campo. 2016. 229 f. Dissertação (Mestrado em Educação) - Programa de Pós-Graduação em Educação, Universidade Federal do Espírito Santo, Vitória, 2016.

ANTUNES-ROCHA, Maria Isabel. Da educação rural à educação do campo: construindo caminhos. In: CARVALHO, Carlos Henrique de; CASTRO, Magali de (org.). Educação rural e do campo. Uberlândia: EDUFU, 2014. p. 13-32.

ARANHA, Maria Salete Fábio. Paradigmas da relação da sociedade com as pessoas com deficiência. Revista do Ministério Público do Trabalho, São Paulo, ano XI, n. 21, p. 160-173, mar. 2001.

ARROYO, Miguel Gonzalez; CALDART, Roseli Salete; MOLINA, Mônica Castagna. Apresentação. In: ARROYO, Miguel Gonzalez; CALDART, Roseli Salete; MOLINA, Mônica Castagna (org.). Por uma educação do campo. 5. ed. Petrópolis: Vozes, 2011. p. 7-18.

AZEVEDO, Janete M. Lins de. A educação como política pública. Campinas, SP: Autores Associados, 1997.

BHABHA, Homi K. O local da cultura. 2. ed. Belo Horizonte: Editora UFMG, 2013.

BRASIL. Constituição da República Federativa do Brasil [1988]. Brasília: Congresso Nacional, 1988.

BRASIL. Lei $n .^{\circ}$ 9.394/96, de 20 de dezembro de 1996. Estabelece as Diretrizes e Bases da Educação Nacional. Brasília: Congresso Nacional, 1996.

BRASIL. Resolução CNE/CEB n. ${ }^{o}$ 2, de 11 de setembro de 2001. Institui Diretrizes Nacionais da Educação Especial na Educação Básica. Brasília: MEC/CNE, 2001.

BRASIL. Diretrizes Operacionais para a Educação Básica nas Escolas do Campo. Brasília: MEC/SECAD, 2002.

BRASIL. Política nacional de educação especial na perspectiva da educação inclusiva [2008]. Brasília: MEC/SEESP, 2008a.

BRASIL. Resolução n. ${ }^{\circ}$ 2, de 28 de abril de 2008. Estabelece diretrizes complementares, normas e princípios para o desenvolvimento de políticas públicas de atendimento da Educação Básica do Campo. Brasília: MEC/ $\mathrm{CNE} / \mathrm{CEB}, 2008 \mathrm{~b}$.

BRASIL. Resolução CNE/CEB $n .^{\circ} 4$, de 2 de outubro de 2009. Institui Diretrizes Operacionais para o Atendimento Educacional Especializado na Educação Básica, modalidade educação especial. Brasília: MEC/CNE/CEB, 2009.

BRASIL. Decreto n. $^{\circ}$ 7.352, de 04 de novembro de 2010. Dispõe sobre a Política de Educação do Campo e o Programa Nacional de Educação na Reforma Agrária (PRONERA). Brasília: Presidência da República, 2010.

BRASIL. Decreto $n^{\circ}$ 7.611, de 17 de novembro de 2011. Dispõe sobre a educação especial, o atendimento educacional especializado e dá outras providências. Brasília: Presidência da República, 2011.

BRASIL. Lei n. $^{\circ}$ 13.005, de 25 de junho de 2014. Aprova o Plano Nacional de Educação - PNE e dá outras providências. Brasília: Congresso Nacional, 2014.

BRASIL. Lei n. $^{\circ}$ 13.146, de 06 de julho de 2015. Institui a Lei Brasileira de Inclusão da Pessoa com Deficiência (Estatuto da Pessoa com Deficiência). Brasília: Congresso Nacional, 2015.

BRUNO, Marilda Moraes Garcia. Diretrizes nacionais de educação especial: convergências e divergências para sua implementação. In: CARVALHO, Carlos Henrique de (org.). Desafios da produção e da divulgação do conhecimento. Uberlândia, MG: EDUFU, 2012. p. 99-114.

BUENO, José Geraldo Silveira. As políticas de inclusão escolar: uma prerrogativa da educação especial? In: 
BUENO, José Geraldo Silveira; MENDES, Geovana Mendonça Lunardi; SANTOS, Roseli Albino dos. Deficiência e escolarização: novas perspectivas de análise. Araraquara, SP: Junqueira\&Marin; Brasília: CAPES, 2008. p. 43-63.

CAIADO, Katia Regina Moreno. Educação especial nas escolas do campo: análise de um silêncio histórico. Anais [...] Encontro Nacional de Pesquisa em Educação do Campo. 3., 2010. Brasília: UnB, 2010.

CAIADO, Katia Regina Moreno; GONÇALVES, Taísa Grasiela Gomes Liduenha. Educação especial em escolas do campo: análise de um município do Estado de São Paulo. Revista HISTEDBR On-line, Campinas, n. 50 (especial), p. 179-193, maio 2013.

CAIADO, Katia Regina Moreno; MELETTI, Sílvia Márcia Ferreira. Educação especial na educação do campo: 20 anos de silêncio no GT 15. Rev. Bras. Ed. Esp., Marília, v. 17, p. 93104, maio/ago. 2011. Edição Especial.

CALDART, Roseli Salete. Por uma educação básica do campo: traços de uma identidade em construção. In: ARROYO, Miguel Gonzalez; CALDART, Roseli Salete; MOLINA, Mônica Castagna (org.). Por uma educação do campo. 5. ed. Petrópolis: Vozes, 2011. p. 147-158.

CANCLINI, Néstor García. Culturas híbridas: estratégias para entrar e sair da modernidade. 4. ed. São Paulo: Editora da Universidade de São Paulo, 2013.

CURY, Carlos Roberto Jamil. Políticas inclusivas e compensatórias na educação básica. Cadernos de Pesquisa, v. 35, n. 124, p. 11-32, jan./abr. 2005.

FERNANDES, Bernardo Mançano; CERIOLI, Paulo Ricardo; CALDART, Roseli Salete. Primeira Conferência Nacional "Por Uma Educação Básica do Campo": texto preparatório. In: ARROYO, Miguel Gonzalez; CALDART, Roseli Salete; MOLINA, Mônica Castagna (org.). Por uma educação do campo. 5. ed. Petrópolis: Vozes, 2011. p. 19-62.

FLEURI, Reinaldo Matias. Políticas da diferença: para além dos estereótipos na prática educacional. Educ. Soc., Campinas, v. 27, n. 95, p. 495-520, maio/ago. 2006.

FOUCAULT, Michel. Segurança, território e população. São Paulo: Martins Fontes, 2008.

FOUCAULT, Michel. A ordem do discurso. 20. ed. São Paulo: Loyola, 2010a.

FOUCAULT, Michel. Microfísica do poder. Rio de Janeiro: Graal, 2010b.

FOUCAULT, Michel. Os anormais. 2. ed. São Paulo: WMF Martins Fontes, 2010c.

FOUCAULT, Michel. Vigiar e punir: história da violência nas prisões. 38. ed. Petrópolis: Vozes, 2010d.

FOUCAULT, Michel. Em defesa da sociedade. 2. ed. São Paulo: WMF Martins Fontes, 2010e.

FOUCAULT, Michel. O sujeito e o poder. In: DREYFUS, Hubert L.; RABINOW, Paul. Michel Foucault: uma trajetória filosófica: para além do estruturalismo e da hermenêutica. 2. ed. Rio de Janeiro: Forense Universitária, 2010f.

GLAT, Rosana; BLANCO, Leila de Macedo Varela. Educação Especial no contexto de uma Educação Inclusiva. In: GLAT, Rosana (org.). Educação Inclusiva: cultura e cotidiano escolar. Rio de Janeiro: 7Letras, 2009. p. 15-35.

GLAT, Rosana; PLETSCH, Marcia Denise. Inclusão escolar de alunos com necessidades especiais. Rio de janeiro: EdUERJ, 2011.

LACLAU, Ernesto. Emancipação e diferença. Rio de Janeiro: EdUERJ, 2011.

MAZZOTTA, Marcos José Silveira. Educação especial no Brasil: história e políticas públicas. 5. ed. São Paulo: Cortez, 2005.

MENDES, Enicéia Gonçalves. A radicalização do debate sobre inclusão escolar no Brasil. Revista Brasileira de Educação, v. 11, n. 33, p. 387-405, set./dez. 2006.

MENDES, Enicéia Gonçalves. Breve histórico da educação especial no Brasil. Revista Educación y Pedagogía, v. 22, n. 57, p. 93-109, maio/ago. 2010. 
MENDES, Enicéia Gonçalves; MALHEIRO, Cícera A. Lima. Sala de recursos multifuncionais: é possível um serviço "tamanho único" de atendimento educacional especializado? In: MIRANDA, Theresinha Guimarães; GALVÃO FILHO, Teófilo Alves (org.). O professor e a educação inclusiva: formação, práticas e lugares. Salvador: EDUFBA, 2012. p. 349-365.

MINISTÉRIO DA EDUCAÇÃO (MEC). Secretaria de Educação Continuada, Alfabetização, Diversidade e Inclusão. Disponível em: http://portal.mec.gov.br/secretaria-de-educacao-continuada-alfabetizacaodiversidade-e-inclusao/apresentacao. Acesso em: 15 out. 2019.

MUNARIM, Antônio. Prefácio: Educação do campo: desafios teóricos e práticos. In: MUNARIM, Antônio et al. Educação do campo: reflexões e perspectivas. 2. ed. Florianópolis: Insular, 2011. p. 9-18.

NOZU, Washington Cesar Shoiti. Política e gestão do atendimento educacional especializado nas salas de recursos multifuncionais de Paranaíba/MS: uma análise das práticas discursivas e não discursivas. 2013. 241 f. Dissertação (Mestrado em Educação) - Programa de Pós-Graduação em Educação, Universidade Federal da Grande Dourados, Dourados, 2013.

PIRES, Angela Monteiro. Educação do campo como direito humano. São Paulo: Cortez, 2012.

PORTES, Écio Antônio; SANTOS, Apolliane Xavier Moreira dos. Educação rural e educação do campo a partir de conceituações teóricas e dados empíricos de diferentes contextos de pesquisa. In: CARVALHO, Carlos Henrique de; CASTRO, Magali de (org.). Educação rural e do campo. Uberlândia: EDUFU, 2014. p. 6199.

QUEIROZ, João Batista Pereira de. Construção das Escolas Famílias Agrícolas no Brasil - ensino médio e educação profissional. 2004. Tese (Doutorado em Sociologia) - Programa de Pós-Graduação em Sociologia, Universidade de Brasília, Brasília, 2004.

SANTOMÉ, Jurjo Torres. As culturas negadas e silenciadas no currículo. In: SILVA, Tomaz Tadeu da (org.). Alienígenas na sala de aula: uma introdução aos estudos culturais em educação. 11. ed. Petrópolis, RJ: Vozes, 2013. p. 155-172.

SANTOS, Boaventura de Sousa. A gramática do tempo: por uma nova cultura política. 3. ed. São Paulo: Cortez, 2010.

SILVA, Lourdes Helena da. Educação do campo e pedagogia da alternância: diversidade, desafios e perspectivas das experiências no Brasil. In: CARVALHO, Carlos Henrique de; CASTRO, Magali de (org.). Educação rural e do campo. Uberlândia: EDUFU, 2014. p. 101-118.

SILVA, Tomaz Tadeu da. A produção social da identidade e da diferença. In: SILVA, Tomaz Tadeu da (org.). Identidade e diferença: a perspectiva dos Estudos Culturais. 14. ed. Petrópolis, RJ: Vozes 2014. p. 73-102.

SKLIAR, Carlos. É o outro que retorna ou é um eu que hospeda?: notas sobre a pergunta obstinada pelas diferenças em educação. In: REUNIÃO ANUAL DA ANPED, 25, 2002, Caxambú. Anais [...] Caxambú: ANPED, 2002. Disponível em: http://www.anped.org.br/25/sessoesespeciais/carlosskliar.doc. Acesso em: 09 maio 2016.

WESCHENFELDER, Noeli Valentina. Uma história de governamento e de verdades - educação rural no RS 1950/1970. 2003. 210 f. Tese (Doutorado em Educação) - Programa de Pós-Graduação em Educação, Universidade Federal do Rio Grande do Sul, Porto Alegre, 2003.

WOODWARD, Kathryn. Identidade e diferença: uma introdução teórica e conceitual. In: SILVA, Tomaz Tadeu da (org.). Identidade e diferença: a perspectiva dos Estudos Culturais. 14. ed. Petrópolis, RJ: Vozes, 2014. p. 7-72. 


\section{Correspondência}

Washington Cesar Shoiti Nozu. Professor da Faculdade de Educação, Universidade Federal da Grande Dourados - UFGD.

ORCID: 0000-0003-1942-0390.

E-mail: washingtonnozu@ufgd.edu.br

Marilda Moraes Garcia Bruno. Doutora em Ensino da Educação Brasileira pela Universidade Estadual Paulista - Júlio de Mesquita Filho. Atualmente é professora associada aposentada da Universidade Federal da Grande Dourados (UFGD), professora do Programa de Pós-Graduação em Educação da Faculdade de Educação e pesquisadora da Linha Educação e Diversidade.

ORCID: 0000-0002-1568-2185.

E-mail: marildabruno@ufgd.edu.br

Texto publicado em Currículo sem Fronteiras com autorização dos autores. 